\author{
Natalie MORENO-KAMIŃSKA \\ Uniwersytet Łódzki \\ n.moreno.kaminska@gmail.com
}

\title{
PRZEMIANY WE WSPÓŁCZESNEJ FRANCJI W KONTEKŚCIE ZACIERANIA SIĘ GRANIC KULTUROWYCH - PERSPEKTYWA KULTUROZNAWCZA NA WYBRANYCH PRZYKŁADACH
}

ABSTRACT Transformations in Contemporary France in the Context of Considering Cultural Borders - A Cultural Perspective in Selected Case Studies Culture in France, as well as its society, is changing. Mobility, the decline of traditional religiosity, and the takeover of global cultural patterns are just a few manifestations of the evolution of French contemporary culture. Based on the concept of culture transfer by French scientists, Michel Espagne and Michael Werner, and Gordon Mathews' "cultural supermarket", the author will present examples and effects of infiltration of foreign cultures and attempts to maintain the distinctiveness and cultural identity of the French.

Keywords: French cuisine, culinary heritage, culinary trails, France

Słowa kluczowe: kuchnia francuska, dziedzictwo kulinarne, szlaki kulinarne, Francja 


\section{WPROWADZENIE}

Jednym $\mathrm{z}$ podejmowanych $\mathrm{w}$ ostatnich latach tematów, pojawiającym się $\mathrm{w}$ dyskusjach przedstawicieli różnych nauk humanistycznych i społecznych, takich jak kulturoznawstwo, antropologia kulturowa czy socjologia, jest kwestia wpływu współczesnej migracji ludności oraz globalizacji na kultury narodowe. Zjawiska te prowadzą do nieustannych przemian społecznych, przenikania się wspólnot narodowych i grup etnicznych, a w konsekwencji do zacierania się granic kulturowych w czasach ponowoczesnych.

Celem niniejszego opracowania jest przedstawienie wybranych przykładów przenikania obcych wpływów do kultury francuskiej i ich efektów na gruncie lokalnym, narodowym oraz odpowiedź na pytania badawcze: czy Francuzi podtrzymują tożsamość narodową w kontekście „transferu kultury”, czy jest on w pełni dokonany oraz jaki jest ich stosunek do przemian w kulturze narodowej.

Ukazane zostaną najbardziej charakterystyczne zdaniem autorki przemiany kulturowe. Jednocześnie wybór, ze względu na wielość przejawów przejęcia obyczajów z innych kultur, został dokonany tak, aby zaprezentować dwie odmienne koncepcje badawcze, ukazujące kulturę z różnych perspektyw. Pierwszą z nich jest metoda „transferu kultury" opracowana przez Michela Espagne’a i Michaela Wernera, która kładzie nacisk na przemiany zachodzące w konkretnych kulturach narodowych. Należy też odpowiedzieć na pytanie, czy analizowane transfery kultury są zakończone, w pełni ukształtowane. Druga idea, „supermarketu kultury”, autorstwa Gordona Mathewsa, zakłada odchodzenie od kultur narodowych na rzecz zglobalizowanej kultury, w której mieszczą się wszystkie tradycyjne elementy charakterystyczne niegdyś dla poszczególnych grup narodowych. Dziś są one dostępne w każdym zakątku świata.

Ze względu na specyfikę zagadnienia, zakładającą wieloaspektowe badanie francuskiej kultury, wykorzystane zostały metody o charakterze interdyscyplinarnym. Dokonana została analiza publikacji naukowych, popularnonaukowych i innych związanych z omawianą tematyką. Wykorzystano materiały z polskich, francuskich i brytyjskich stron internetowych. Wprowadzono odniesienia historyczne. Przeprowadzono także obserwacje i rozmowy z Francuzami dotyczące ich stosunku do przemian we własnej kulturze narodowej.

\section{KONCEPCJA TRANSFERU KULTURY MICHELA ESPAGNE'A I MICHAELA WERNERA}

Koncepcja transferu kultury (niem. Kulturtransfer) jest efektem współpracy francuskich naukowców, specjalistów z zakresu literaturoznawstwa, germanistyki oraz historioznawstwa z Centre National de la Recherche Scientifique w Paryżu, którzy uznali za potrzebną zmianę metody analizowania wpływów kulturowych między Francją i Niemcami w XX w. Dotychczas badacze stosowali głównie metodę porównawczą. Omówienie ich programu badawczego autorstwa Michela Espagne’a i Michaela Wernera ukazało się na 
łamach czasopisma „Francia” w 1985 r. ${ }^{1}$ Kluczowym aspektem stało się dla nich określenie, w jaki sposób zachodnie kultury importują i przyswajają nowe i obce im treści (wartości, sposób myślenia itp. $)^{2}$. Koncepcja transferu kultury jest narzędziem stosowanym w analizie czynników charakterystycznych dla przepływu kulturowego przez badaczy podejmujących kwestie związane z zagadnieniami wielokulturowości czy transkulturowości. Pozwala ona uchwycić charakter zachodzących przemian i wymiany dóbr kulturowych między obszarami heterogenicznymi z innej perspektywy oraz poddać je refleksji. Ideą pomysłu jest badanie kilku kluczowych aspektów, np. koniunktury, rozumianej jako splot wielorakich okoliczności i warunków, wywierajacych pozytywny wptyw na badany element trans$f e r u^{3}$. Zgodnie z tym założeniem transfer jest zależny od gotowości przyjęcia wpływów w kulturze pochodnej, a nie od siły oddziaływania i ekspansji kultury pierwotnej (obcej). Perspektywa ta pozwala przyjąć, że w kulturze przyjmującej zakorzenią się elementy z jej perspektywy deficytowe, na które jest zapotrzebowanie. Może ono wynikać z panującej mody, fali emigracji czy wskazania społecznego lidera. Takie rozumowanie nie przedstawia obcych wpływów w sposób negatywny, ale wskazuje, że są użyteczne. Jak pisze Lena Magnone: poszukiwanie wptywów jednego autora na innego zawsze milczaco zaktada niższość kultury przyjmujacej oraz koncentruje się wokót pytania o wierność wobec modelu. [...] Teoria transferu kulturowego jest szczególnie przydatna do jednoczesnego badania wielu przestrzeni narodowych, jednak nie po to, by je konfrontować ze soba, lecz w celu wydobycia dowodów na ich nieautarkiczność, różnych form kulturowej „metyzacji ${ }^{\prime \prime 4}$. Matthias Middell ${ }^{5}$ twierdzi z kolei, że nie chęć eksportu, ale gotowość importu steruje w gruncie rzeczy procesami transferu kultury ${ }^{6}$. Należy zaznaczyć, że pojęcie transferu zostało zapożyczone z języka nauk ekonomicznych. $Z$ tego względu w koncepcji stosowane są takie określenia jak import, eksport czy koniunktura recepcyjna.

Kolejnym aspektem odgrywającym w koncepcji Espagne’a i Wernera istotną rolę są pośrednicy (niem. Vermittler) - osoby, grupy społeczne czy instytucje, które zgodnie ze swoimi potrzebami dokonują zapośredniczenia konkretnych treści czy elementów z kultury obcej poprzez naśladownictwo. Badacz, posługując się koncepcją transferu kultury, patrzy na analizowany materiał ściśle empirycznie. Jego zadaniem jest ocenić fakty i ich wzajemne zależności, czy w określonym czasie i przestrzeni znajdowały się realne przedmioty lub odbyły się zdarzenia wskazujące na zapośredniczenie z odrębnej kultury ${ }^{7}$. Tylko wtedy potwierdzenie recepcji z innej kultury jest możliwe. W języku

K. Prykowska-Michalak, Kurtyna w górę! Relacje między teatrem polskim a teatrem niemieckim po 1990 roku, Łódź 2012, s. 35.

Tamże.

Tamże, s. 37.

L. Magnone, Emisariusze Freuda. Transfer kulturowy psychoanalizy do polskich sfer inteligenckich przed druga wojna światową, t. 1, Kraków 2016, s. 6.

Badacz wpływów kulturowych, globalizacji, historyk kultury, profesor na Uniwersytecie w Lipsku.

$6 \quad$ K. Prykowska-Michalak, Kurtyna w górę..., s. 37.

M. Freise, Próba typologii podstawowych zagadnień komparatystycznych, „Litteraria Copernicana” 2015, nr 2, s. 16 . 
francuskim pojęcie transferu odnosi się do fizycznego przesunięcia przedmiotu w przestrzeni, przeniesienia go z jednego miejsca na drugie, co podkreśla konieczność rzeczywistego transportu osób czy rzeczy ${ }^{8}$. Dzięki określeniu warunków otwartości recepcyjnej lub trwałości tradycji panujących w kulturze przyjmującej, które oddziałują na sposób i moment wpływu oraz ciągu przyczynowo-skutkowego wymiany międzykulturowej, możliwe jest określenie konkretnych potrzeb, które stanowity jego podstawę. Badacz zwraca uwagę na punkty oporu wobec prób transferu, jeżeli taki miał miejsce?

Hans-Jürgen Lüsebrink na podstawie badań Espagne’a i Wernera wydzielit trzy podstawowe procesy stymulujace transfer kultury. Sq to: proces selekcji, proces zapośredniczenia oraz proces recepcji ${ }^{10}$. Efektem badań prowadzonych tą metodą jest określenie, czy i w jaki sposób doszło do akulturacji albo recepcji, rozumianej - co należy podkreślić - jako zakorzenienie wpływu w kulturze przyjmującej. Jeżeli zostanie ona potwierdzona, uznaje się transfer kulturowy za dokonany.

Kończąc opis koncepcji Espagne’a i Wernera, należy jeszcze raz podkreślić, że zdaniem autorów to ludzie czy instytucje, kierując się swoimi potrzebami, dokonują wyboru i zakorzeniają obce wpływy w swojej kulturze. W sposób uzupełniający można przedstawić koncepcję Gordona Mathewsa, który zwraca uwagę na to, że ludziom jedynie wydaje się, iż pewne elementy wybierają z supermarketu kultury ${ }^{11}$.

\section{KONCEPCJA SUPERMARKETU KULTURY GORDONA MATHEWSA}

Gordon Mathews w publikacji Supermarket kultury. Kultura globalna a tożsamość jednostki podkreśla, że choć mówimy o kulturze japońskiej, kulturze francuskiej, kulturze chińskiej [...], zaktadając z góry, że mniej więcej wiadomo, co te etykietki oznaczają ${ }^{12}$, a ludzie definiują siebie poprzez przynależność do danej kultury narodowej, to jednak nie mogą zachować odrębności, czerpiąc ze wszystkich kultur świata ${ }^{13}$. Wybierając z nich preferowane elementy, każdy człowiek tworzy własne uniwersum kulturowe. Wśród czynników wpływających na zjawisko zacierania się tożsamości lokalnej czy narodowej Mathews wymienia m.in. globalne prądy, interakcje, szybki przepływ idei, informacji, kapitału i ludzi. Jego zdaniem człowiek żyje w świecie, dla którego kultura jest modą, kwestią gustu poszczególnych jednostek, a eklektyzm punktem wyjścia. W przeciwieństwie do Espagne’a i Wernera, badacz wskazuje, że wybór przedmiotu międzykulturowej wymiany nie jest wolny, bowiem parafrazując jego założenie, można powiedzieć, że potrzeba jest ściśle uwarunkowana wiekiem, przynależnością klasową, płcią,

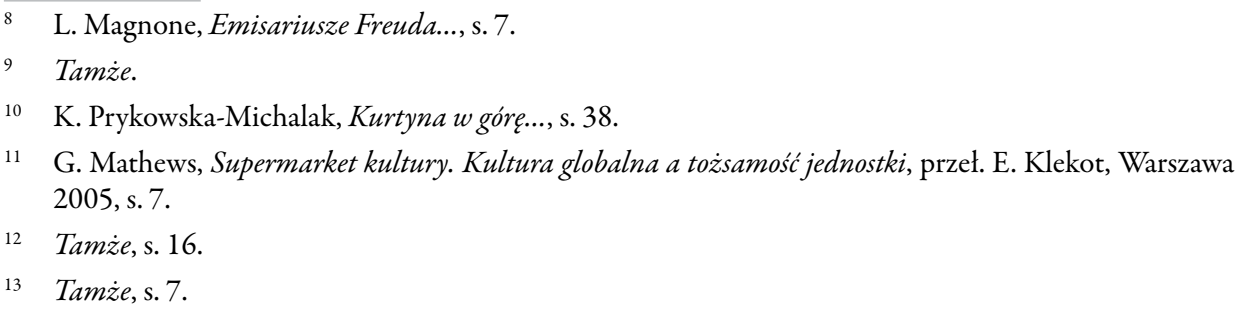


wierzeniami religijnymi, obywatelstwem i stopniem zamożności. Dopiero wtedy odzywa się wcześniej ukształtowane (według tego, co człowiek wyniósł z domu) „ja”. Kontynuując tę myśl, nie byłoby bezzasadnym stwierdzenie, że nawet jeśli jakiś element został zakorzeniony w kulturze przyjmującej za sprawą potrzeby, to jednak był on czynnikiem deficytowym dla wybranych jednostek, nie zaś dla wszystkich przedstawicieli tej kultury. Mathews podkreśla, że współcześnie człowiek ma do czynienia z tożsamością kreowaną przez rynek. Tożsamość rozumiana jako punkt zaczepienia, zgodnie z którym jednostka pojmuje i klasyfikuje samą siebie ${ }^{14}$, pozwala jej zdobyć poczucie zakorzenienia i jedności w obrębie danego kręgu kulturowego, a także daje jej poczucie odrębności. Odchodzi się zatem od charakterystycznych w czasach nowoczesnych kultur narodowych na rzecz kultury zglobalizowanej.

\section{PRZEMIANY I ICH EFEKTY W KULTURZE FRANCUSKIEJ}

O Francji będącej kolebką cywilizacji i jej szeroko rozumianej historii i kulturze powstało już wiele ciekawych i obszernych publikacji, jednak żadna nie wyczerpuje w pełni tematu. Wymienić można choćby Jacquesa Bainville’a Dzieje Francji ${ }^{15}$, Philippe’a Poirriera Société et Culture en France depuis 1945 ${ }^{16}$, Alfreda Cobbana A History of Modern France ${ }^{17}$, Ludwika Straszewicza Francja ${ }^{18}$, Jean-Yvesa Potela, Marka Rapackiego i Marcina Frybesa Francja ta sama czy inna? ${ }^{19}$ czy Johna Ardagha Wielkie kultury świata. Francja $a^{20}$. Na potrzeby artykułu uwaga szczególnie zostanie zwrócona na dwie pozycje dostępne polskiemu czytelnikowi: Georgesa Duby'ego i Roberta Mandrou Historię kultury francuskiej $X-X X$ w., a także Dzieje kultury francuskiej autorstwa Jacka Kowalskiego, Anny i Mirosława Lobów oraz Jana Prokopa ${ }^{21}$. Zawierają one wiele szczegółowych opisów dotyczących kultury Francji i jej historii, a także poruszają istotne tematy polityczne, społeczne, czasem ekonomiczne. Wskazują także na odrębność kultur regionalnych. W dalszej części tego artykułu poruszone zostaną tylko wybrane kwestie związane z kulturą francuską, które będą ważne dla późniejszej analizy.

Przez kolejne wieki kultura francuska proponowała innowacyjne rozwiązania w nauce, sztuce czy technologii, tworzyła nowe nurty, wskazywała trendy, nieodmiennie inspirując inne kultury. Szczególną rolę nie tylko dla samej kultury francuskiej, ale także europejskiej odegrała rewolucja francuska: Za przetomowy moment $w$ dziejach, będący początkiem dążenia ludzkości europejskiej do nowoczesności, należy uznać okres Wielkiej

\footnotetext{
Tamże, s. 36.
}

15 J. Bainville, Dzieje Francji, przeł. T. Stryjeński, Komorów 2010.

16 Ph. Poirrier, Société et Culture en France depuis 1945, Paris 1998.

17 A. Cobban, A History of Modern France, Vol. 1, Harmondsworth 1965.

18 L. Straszewicz, Francja, Warszawa 1972.

19 J.-Y. Potel, M. Rapacki, M. Frybes, Francja ta sama czy inna?, Warszawa 2009.

20 J. Ardagh, C. Jones, Wielkie kultury świata. Francja, przeł. J. Pierzchała, M. Dziekan, Warszawa 1998.

21 J. Kowalski, A. i M. Loba, J. Prokop, Dzieje kultury francuskiej, Warszawa 2005. 
Rewolucji Francuskiej w latach 1789-1799, której hasta „Wolność, Równość, Braterstwo"22 można odnaleźć choćby w mowach i dziataniach wspótczesnych dyplomatów europejskiej spoteczności międzynarodowej. Przyjmuje się, że obalenie monarchii i rewolucja w imię równości stanów zapoczątkowata demokracje konstytucyjna. Od tego czasu uznano za obowiazująca zasadę suwerenności państw narodowych, co tącznie z oświeceniowymi ideatami rozumu ipostęp w konsekwencji nadato instytucjonalna ramę czasom nowoczesnym ${ }^{23}$. Nastąpił upadek monarchii absolutnej, a wraz z nim zniesiony został ustrój feudalny. Upowszechniły się zasady wolności słowa oraz równości wobec prawa. Deklaracja Praw Człowieka i Obywatela stała się symbolem walki o równość społeczną i wzorem systemu wartości dla przedstawicieli innych krajów.

Rewolucja odegrała znaczącą rolę w historii z punktu widzenia świadomości wyznania. Nastąpił rozdział instytucji Kościoła od państwa, przez co zmniejszył się wpływ tego pierwszego na społeczeństwa narodowe. Wprowadzono swobodę wyznaniową. Można zatem uznać, że rewolucja francuska przyspieszyła proces unowocześnienia Europy.

Pisząc o kulturze Francji, warto zwrócić szczególną uwagę na francuską sztukę kulinarną, która stanowi istotny aspekt w podtrzymywaniu tożsamości narodowej. Szeroko pojmowana kuchnia francuska była pielęgnowana na dworze królewskim i wśród arystokracji, jednak sam posiłek był też ceniony przez mieszczan. Francja chlubi się słynnym filozofem jedzenia, Anthelmem Brillat-Savarinem, autorem dzieła Fizjologia smaku albo Medytacje o gastronomii doskonatej, oraz wielkimi mistrzami kulinarnymi, takimi jak François Pierre de la Varenne, Marie-Antoine Carême, Auguste Escoffier, Paul Bocuse czy Alain Ducasse, którzy zrewolucjonizowali kuchnię francuską w różnych okresach jej rozwoju i wywarli wpływ na kuchnie świata.

Współcześnie coraz więcej badaczy zwraca uwagę na rozproszenie kultur i tożsamości narodowych, które związane jest z różnymi zjawiskami ponowoczesności. Mimo iż kultura francuska w dyskursie publicznym ukazywana jest przez pryzmat swoich największych osiągnięć i cech charakterystycznych, kreujących stereotyp Francuza, to jednak w coraz większym stopniu dostrzega się zmiany, jakie w ostatnim ćwierćwieczu zachodzą we Francji. Marc Fumaroli w książce Państwo kulturalne. Religia nowoczesności, opublikowanej po raz pierwszy w 1990 r., poddał analizie sytuację francuskiej kultury. Już wtedy pisał tak: Jeszcze mówi się o francuskim spoteczeństwie, o francuskiej polityce kulturalnej, jednak uzywa się tego przymiotnika wytacznie dla wygody, by opisać to, co bezpośrednio aktualne: ptynne trendy i sondażowe opinie poddane presji "wydarzenia" ${ }^{24}$. Wypowiedź ta świadczy o bliskości jego krytycznego spojrzenia na zmiany zachodzące we Francji i idei Gordona Mathewsa. Warto przyjrzeć się więc zmianom, które nastąpiły we Francji w kolejnych latach, łącząc je z odniesieniami historycznymi.

22 Fr. Liberté, Egalité, Fraternité.

23 N. Moreno-Kamińska, Problematyka tożsamości kulturowej spoteczeństw ponowoczesnych w naukach bumanistycznych - aspekty kulturoznawcze, [w:] Nauki spoteczne i humanistyczne wobec wyzwań XXI wieku, red. K. Pujer, Wrocław 2017, s. 84.

24 M. Fumaroli, Państwo kulturalne. Religia nowoczesności, przeł. H. Abramowicz. J.M. Kłoczowski, Kraków 2008, s. 40. 
Problemem często pojawiającym się w dyskursie publicznym związanym z kwestią wpływu obcych kultur na społeczeństwo francuskie jest odchodzenie od religii katolickiej. Francję podaje się jako przykład państwa, którego społeczeństwo przeżywa głęboki kryzys wiary, które porzuciło swoje chrześcijańskie korzenie. Uwaga badaczy - socjologów, ekonomistów, politologów - często koncentruje się na sytuacji muzułmańskiej populacji imigranckiej wyodrębnionej na podstawie kryterium wyznaniowego. Odnosząc się do koncepcji Espagne’a i Wernera, należy zbadać, jaka jest przyczyna tej przemiany i czy jest ona na tyle trwała, aby określić ją mianem transferu kultury. Najistotniejsze będą w tej kwestii proces zapośredniczenia oraz recepcji.

Na wstępie należy zaznaczyć, że Francja nazywana była przez papieży „najstarszą córą Kościoła”. Od czasów Chlodwiga królowie Franków podkreślali swoje związki z katolicyzmem. Wielką reformę papieża Grzegorza VII dotyczącą likwidacji świeckiej inwestytury zapowiedział właśnie we Francji, w Reims, Leon IX. Co istotne, już w XI w. rozwinięta była tzw. religia królewska, a więc ideologia głosząca, że monarcha jest wybrańcem naznaczonym przez Boga i wypełnia jego wolę ${ }^{25}$. Na początku XVI w. Awinion na południu kraju stał się stolicą papiestwa, kiedy w 1309 r. osiadł tam z kurią papież Klemens V. Dopiero Grzegorz XI powrócił do Rzymu w 1377 r. Jak zwraca też uwagę Jan Baszkiewicz: francuskim wktadem do reformacji europejskiej byt oczywiście kalwinizm. Jean Calvin dużo lepiej niż Luter rozumiat, że staremu Kościotowi "papistów" przeciwstawić należy Kościót nowy, surowszy, wsparty na bojaźni Bożej ${ }^{26}$. Ruch ten, jak wiadomo, nigdy jednak w skali globalnej nie zagroził katolicyzmowi. Kalwińska mniejszość w edykcie nantejskim wydanym przez Henryka IV Burbona w 1598 r. uzyskała wolność wyznania i swobodę kultu, co przyczyniło się do zakończenia trwających przez 30 lat wojen religijnych we Francji. Proces przemian wyznaniowych zapoczątkował Ludwik XIV, który zniósł edykt i powrócił do idei „Jedna wiara, jeden król, jedno prawo"27.

W okresie jego panowania zaczął rodzić się jansenizm ${ }^{28}$, ruch teologiczny, który stał się przyczyną kryzysu francuskiego Kościoła katolickiego. Ruch ten dystansował się od autorytarnego i centralistycznego modelu sprawowania władzy w Kościele, popierał równość władzy biskupów ${ }^{29}$. Sposób osiągnięcia zbawienia stał się przedmiotem najdtuższego oraz najbardziej dramatycznego i zaciętego sporu teologicznego $w$ dziejach Francji. Byt on prowadzony między jansenistami, których popierali augustianie, oratorianie $i$ karmelici, a jezuitami wspieranymi przez papiestwo i kard. Richelieu [...], pierwszego ministra dworu króla Francji Ludwika XIII ${ }^{30}$. W latach poprzedzających wielką

25 J. Baszkiewicz, Francja w Europie, Wrocław 2006, s. 167.

26 Tamże, s. 171.

27 Tamże, s. 172-173.

28 Jansenizm miał korzenie niderlandzkie, gdyż został zapoczątkowany przez biskupa Ypres, Corneliusa Ottona Jansena. Jednak po śmierci Jansena głównym obrońcą jego poglądów stał się francuski teolog, Antoine Arnauld. Zob. B. Przedpełski, Kontrowersje wokót jansenizmu, „Rocznik Teologiczny” 2010, t. 52, z. 1-2, s. 234, 242.

29 Tamże, s. 234.

30 Tamże, s. 239. 
rewolucję katolicyzm był słaby - ostatecznie w 1764 r. rząd usunął z kraju zakon jezuitów. Formowanie się państwa laickiego zapoczątkowała Deklaracja Praw Człowieka i Obywatela, która przyjęta zasadę suwerenności Narodu, uznata, iżzadne ciato zbiorowe $i$ żadna jednostka nie może sprawować wtadzy, jeśli ta nie pochodzi wyraźnie z woli Narodu. Oznacza to kres wyobrażeń o wtadzy monarchy, danej mu przez Boga ${ }^{31}$.

Pogorszenie sytuacji praktykujących katolików nastąpiło w 1791 r., gdy biskupi odmówili złożenia przysięgi na konstytucję cywilną, którą potępił Pius VI. Rok później państwo przejęło akta stanu cywilnego, ustanowione zostały śluby i rozwody cywilne, doszło także do masowych aresztowań księży ${ }^{32}$. Z kolei Napoleon przywrócił zasadę konkordatu bolońskiego, na mocy której uzyskał prawo mianowania biskupów. Wydał też artykuły dotyczące kultu katolickiego, dzięki którym Kościół poddano kontroli $\mathrm{rząqu}^{33}$. Powołane zostało także Ministerstwo Wyznań, traktujące na równi wszystkie wyznania, co wpłynęło na postrzeganie religii katolickiej jako jednej z wielu.

Jak widać, w historii francuskiego katolicyzmu zauważalne są wahania, a także zaznaczył się religijny sceptycyzm, naktadanie się antyklerykalizmu na kryzys świadomości religijnej pogtębiato powolna erozję religijności ${ }^{34}$. Konflikty polityczne i uwarunkowania międzynarodowe wpłynęły na osłabienie religijności społeczeństwa. Ostatecznie 9 grudnia 1905 r. z inicjatywy Aristide’a Brianda, ówczesnego parlamentarzysty (późniejszego premiera rządu) została uchwalona ustawa przewidująca rygorystyczny rozdział Kościoła od państwa (fr. la loi de séparation des Églises et de l'État). Od tego czasu Republika Francuska nie uznaje ani nie subwencjonuje żadnej religii, a osobom publicznym nie wolno otwarcie deklarować wyznania. $\mathrm{Z}$ tego względu w dyskursie stosowane jest określenie tego kraju jako państwa laickiego. Należy zauważyć, że w ostatnim ćwierćwieczu nastąpił szczególny zwrot ku ateizacji i islamizacji. Z perspektywy koncepcji Espagne’a i Wernera należy zapytać, jaka jest przyczyna tej przemiany, a więc proces zapośredniczenia.

$\mathrm{Z}$ analiz wynika, że wpływ na to zjawisko miała fala emigrantów. Obecność kilkumilionowej mniejszości wyznawców islamu jest wynikiem francuskich ambicji kolonialnych i prowadzonej przez lata łagodnej polityki imigracyjnej. Największą rolę odegrały migracje ludności z krajów Maghrebu ${ }^{35}$ - Algierii, Maroka, Tunezji - a także z Senegalu, Mali czy Turcji3 ${ }^{36}$. Podpisanie porozumienia w Schengen przez Francję, Republikę Federalną Niemiec i państwa Beneluksu w 1985 r. i jego rozciągnięcie na inne państwa Unii Europejskiej dziesięć lat później umożliwiło nie tylko swobodny przepływ ludności między krajami UE, ale także ułatwiło ujednolicenie przepisów

31 J. Baszkiewicz, Francja w Europie..., s. 179.

32 Tamże, s. 176.

33 Tamże, s. 179.

34 J. Baszkiewicz, Francja nowożytna. Szkice z historii wieków XVII-XX, Poznań 2002, s. 105.

35 Określenie Maghreb, powstałe w czasie ekspansji arabskiej w średniowieczu, stosowane było przez Arabów w stosunku do regionu północno-zachodniej Afryki. Nazwa ta przyjęła się również w językach europejskich.

36 I. Kielan-Glińska, Muzutmanie w laickiej Francji (1974-2004). W kierunku integracji czy separatyzmu?, Kraków 2009, s. 28-30. 
dotyczących azylu czy nielegalnej imigracji ludności z innych obszarów świata. Jak podaje Ilona Kielan-Glińska: w ostatniej dekadzie XX w. zjawisko naptywu ludności z krajów arabsko-muzutmańskich do Francji trwato nadal, lecz miato zdecydowanie odmienny charakter. [...] francuscy decydenci, traktujac cudzoziemców spoza UE nieomal jako zto konieczne, zezwalali na pobyt staty gtównie tym osobom, których taczyty z metropolia więzy rodzinne, [...] kolejne rzady V Republiki testowaty rozmaite instrumentaria prawne w celu ograniczenia naptywu przybyszów spoza Europejskiego Obszaru Gospodarczego ${ }^{37}$.

W 2005 r. we Francji wybuchły zamieszki na przedmieściach Paryża, które rozszerzyły się na inne miejscowości w północno-wschodnim rejonie w skupiskach ludności wyznającej islam, pochodzącej z krajów Maghrebu i Subsaharyjskiej Afryki ${ }^{38}$. Stały się impulsem do wprowadzenia reformy polityki imigracyjnej i integracyjnej, której inicjatorem był ówczesny minister spraw wewnętrznych, późniejszy prezydent, Nicolas Sarkozy. Wprowadzono przepisy prawne, które ograniczają swobodny dostęp do rynku krajowego, by wykluczyć imigrantów o niskim poziomie wykształcenia i niewystarczających kwalifikacjach zawodowych. „Selektywną selekcję" mają umożliwiać umowy o przyjęciu $i$ integracji, do których przestrzegania zobowiązują się legalni cudzoziem$\mathrm{cy}^{39}$. Reforma rozpoczęła proces rekonstrukcji polityki imigracyjnej nie tylko na szczeblu krajowym, ale i w Unii Europejskiej. 18 czerwca 2008 r. Parlament Europejski (PE) przyjąt projekt dyrektywy w sprawie wspólnych norm i procedur odsytania nielegalnych imigrantów pochodzacych z państw trzecich. W październiku Rada Europejska (RE) przyjęta Pakt europejski o imigracji i azylu w wyniku inicjatywy francuskiej prezydencji, który przewidywat harmonizacje polityk publicznych w tym zakresie w UE. W ten sposób na szczeblu europejskim zostat zatwierdzony kierunek, który swojej polityce migracyjnej Francja nadata $w$ potowie lat $70 .^{40}$

Według oficjalnych danych INSEE w 2008 r. Francja liczyła ponad $5 \mathrm{mln}$ trzysta tysięcy imigrantów z różnych regionów świata, z czego 42,5\% stanowiła ludność przybyła z Afryki ${ }^{41}$. Według analiz we Francji żyje 5-6 mln muzułmanów ${ }^{42}$, a ich populacja nad Sekwaną cały czas się powiększa. Z kolei Jean-Paul Gourévitch w badaniach z 2007 r. szacował, że wyznawców islamu jest około $7 \mathrm{mln}^{43}$. Nie jest możliwe

\section{Tamize, s. 35 .}

38 Nadal trwaja zamieszki we Francji, PAP, 2005, [online] http://www.money.pl/archiwum/wiado mosci/artykul/nadal;trwaja;zamieszki;we;francji,210,0,130002.html, 26 XI 2017.

39 M. Pachocka, Polityka imigracyjna i integracyjna Francji w okresie prezydentury Nicolasa Sarkozy'ego zarysproblemu, [w:] Wokótproblematyki migracyjnej. Kultura przyjęcia, red. J. Balicki, M. Chamarczuk, Warszawa 2013, s. 65.

40 Tami̇e, s. 68.

41 Tamże, s. 62-63.

42 M. Michalak, Muzutmanie to wielki problem Francji, Interia.pl, 2017, [online] http://fakty.interia. $\mathrm{pl} /$ raporty/raport-wybory-prezydenckie-francja-2017/korespondencje/news-muzulmanie-to-wielki-problem-francji,nId,2389361, 13 XI 2017.

43 K. Gajlewicz-Korab, Obraz muzutmanów we Francji w tamtejszych tygodnikach opinii, Warszawa 2011, s. 41. 
ustalenie konkretnej liczby francuskich muzułmanów, gdyż od 1968 r. funkcjonuje zakaz umieszczania w spisach ludności pytań o wyznawaną religię ${ }^{44}$. Dla koncepcji Espagne’a i Wernera istotne są efekty tego wpływu, a także określenie, czy jest on trwały, aby zaklasyfikować go jako transfer kultury.

Według źródeł, we Francji w okresie ostatnich 25 lat liczba ochrzczonych dzieci zmalała z 73\% w 1990 r. do 29\% w 2015 r. ${ }^{45}$ Jak podkreśla konsul honorowy RP w Nicei Michel Forkasiewicz: Problem jest taki, że to sa ludzie, którzy nie chca się zasymilować. Mamy już $w$ tej chwili trzy generacje pochodzenia muzutmańskiego i nie ma tu żadnych postępów [...]. Sq dwa stowa: integracja i asymilacja. Asymilacja to żyćjak Francuzi, wypowiadać się jak Francuzi, poślubić tę sama kulture, poślubić ten sam ubiór. Integracja to tylko pierwszy krok - przyjeżdza pan gdzieś, zamieszkuje pan tam, no i jest pan zintegrowany. Ktadęnacisk na asymilacje, dlatego że 60-70 procent obywateli arabskiego pochodzenia nie chce się asymilować, nie chce uznać francuskich zwyczajów i kultury ${ }^{46}$.

Asymilacja jest niezwykle ważna, gdyż następuje zderzenie kultur zupełnie od siebie odmiennych. Jak wiadomo, islam jest religią totalną, obejmującą wszystkie aspekty życia. Jak wynika z prognoz demograficznych amerykańskiego ośrodka badań socjologicznych Pew Research Center, Islam będzie jedyna religia rosnaca szybciej niż ludność planety. Do 2050 r. muzutmanów przybędzie dwa razy więcej niż chrześcijan $(73: 35 \text { proc. })^{47}$. Pojawienie się pełnych rodzin muzułmańskich we Francji spowodowało, że kwestie religijne nabrały jeszcze większej wagi. Wyznawcy Allaha mają więcej dzieci niż rdzenni Francuzi ${ }^{48}$, a obecność potomstwa przekłada się na chęć przekazywania wiary, tradycji i kultury swoich przodków. Grupy wyznawców zaczęły rozszerzać swoje działania i dążyć do zwiększenia dostępności do świątyń. Dalil Boubakeur, rektor Meczetu Paryskiego i przewodniczący Francuskiej Rady Kultu Muzułmańskiego, w wywiadzie udzielonym w 2015 r. dla stacji radiowej Europe 1 wezwał do zamiany kościołów katolickich na meczety i do podwojenia liczby tych drugich we Francji w ciągu dwóch lat. Jego zdaniem świątynie katolickie są puste, a wyznawcom islamu potrzeba minimum pięciu tysięcy meczetów ${ }^{49}$. Spotkało się to z krytyką ze strony ugrupowań

44 I. Kielan-Glińska, Muzutmanie w laickiej Francji..., s. 16.

45 Dramatyczna skala przemian kulturowych we Francji. W ćwierć wieku liczba chrztów zmniejszyta sie o ponad potowę! Wolność24.pl, 2017, [online] http://wolnosc24.pl/2017/05/08/dramatyczna-skala-przemian-kulturowych-we-francji-w-cwierc-wieku-liczba-chrztow-zmniejszyla-sie-o-ponad-polowe/, 19 XII 2017.

46 Muzutmanie to wielki problem Francji...

47 A. Szostkiewicz, Demografia: tajna broń muzutmanów? Niedtugo będzie ich więcej niż chrześcijan, Polityka.pl, 2017, [online] https://www.polityka.pl/tygodnikpolityka/swiat/1698276,1,demogra fia-tajna-bron-muzulmanow-niedlugo-bedzie-ich-wiecej-niz-chrzescijan.read, 1 VIII 2018; Islam: The world's fastest growing religion, BBC News, 2017, [online] https://www.bbc.com/news/av/ world-39279631/islam-the-world-s-fastest-growing-religion, 1 VIII 2018.

48 Jak podaje Pew Research Center, kobieta muzułmanka rodzi statystycznie 3,1 dzieci, a niemuzułmanka 2,3. A. Szostkiewicz, Demografia...

49 Lider muzutmanów we Francji: zamieńmy puste kościoty na meczety, TVN24.pl, 2015, [online] https:// www.tvn24.pl/wiadomosci-ze-swiata,2/lider-muzulmanow-we-francji-zamienmy-puste-koscioly-na-meczety,551981.html, 25 XI 2017. 
konserwatywnych, m.in. Frontu Narodowego, którego przedstawiciele zapowiedzieli, że partia stanowić będzie „opozycję totalną” dla wszystkich, którzy okażą poparcie koncepcji Boubakeura ${ }^{50}$.

Przeciwnicy hegemonii muzułmańskiej twierdzą, że dzisiejszy Kościół we Francji kojarzy się ze zmniejszającą się liczbą praktykujących i spadającą liczbą powołań kapłańskich, czego dowodem może być potrzeba posługi księży misjonarzy z innych państw, w tym również z Polski. Odnosząc się z kolei do koncepcji Gordona Mathewsa, trzeba stwierdzić, że istnieje grupa rdzennych Francuzów, którzy czerpiąc z „supermarketu kultury”, przechodzą na islam. Jak pisze Jean-Marie Gaudeul, zmiana religii wiąże się z pragnieniem duchowości. Podkreśla on, że w wielu przypadkach przynależność do społeczności chrześcijan u Francuzów często jest związana z nominalnym członkostwem lub rutynową praktyką, do której wielu skłoniło się bez odczucia prawdziwej łączności z Bogiem. Przejście na islam staje się świadomym wyborem wynikającym z potrzeby wewnętrznej przemiany i duchowego przekonania ${ }^{51}$. Badacz podkreśla jednak, że są także inne powody, dla których Francuzi decydują się na zmianę wyznania. Zgodnie z regularnie publikowanymi przez wspólnotę muzułmańską w Paryżu statystykami, co roku odnotowuje się około setki nawróceń na islam, w tym jedną trzecią z powodu małżeństwa ${ }^{52}$ : Duszpasterze mtodzieży z catej Francji opowiadaja mi o mtodych z ich duszpasterstw, którzy decyduja się na zmianę religii i to na przyktad tuż po bierzmowaniu. Bardzo często konwersja jest związana z poślubieniem muzutmanina czy muzutmanki. Islam bowiem nie toleruje matżeństw mieszanych. W takich przypadkach chrześcijanie zazwyczaj wyrzekaja się wiary ${ }^{53}$. Celem tego artykułu nie jest krytyka czy też pochwała tego typu działań, tylko zrozumienie mechanizmów zachodzących w kulturze.

Przejście na islam łączy się ze zmianą sposobu życia wielu obywateli francuskich. W niektórych przypadkach młodzi radykalizują się, a nawet przyłączają się do dżihadu, mimo iż zostali wychowani w duchu odmiennych wartości ${ }^{54}$. Na negatywny wizerunek muzułmanów wpłynęły właśnie w dużej mierze liczne zamachy terrorystyczne przeprowadzone we Francji ${ }^{5}$ przez zwolenników tzw. Państwa Islamskiego. Sfrustrowana mtodzież, nawet ta mato zainteresowana praktykami religijnymi, jest szczególnie podatna na agitacje duchownych, którzy postugując się bez zrozumienia wersetami Koranu,

50 Il n'y a pas assez de mosquées en France, „Le Figaro” 2015, [online] http://www.lefigaro.fr/flash-actu/2015/04/07/97001-20150407FILWWW00063-il-n-y-a-pas-assez-de-mosquees-en-france. php, 10 VIII 2018.

51 J.-M. Gaudeul, Changements d'affiliation entre christianisme et islam, „Études” 2004, vol. 11, s. 507.

52 Tamże, s. 502.

53 Mtodzi Francuzi przechodza na islam, Pch24.pl, 2012, [online] http://www.pch24.pl/mlodzi-francuzi-przechodza-na-islam,10282,i.html, 10 XII 2017.

54 Historie takie ukazuje choćby film dokumentalny Zostatem francuskim dżihadystą w reżyserii Xaviera Deleu.

55 Zamachy w Paryżu: w redakcji magazynu „Charlie Hebdo” i przy Stade de France oraz w teatrze Bataclan w 2015 r., w Nicei czy w Saint-Étienne-du-Rouvray na przedmieściach Rouen w 2016 r., przed wejściem do Luwru czy na terenie Pól Elizejskich w 2017 r., w Carcassonne i Trèbes w 2018 r. 
namawiaja ją do przestępstw, a nawet do terroryzmu ${ }^{56}$. Biorąc jednak pod uwagę różnego rodzaju analizy, warto zauważyć, że nie można jednoznacznie stwierdzić, iż we francuskim transferze religijnym przewagę posiadają konwersje na islam. Część muzułmanów przechodzi na chrześcijaństwo, choć wielu fakt ten ukrywa, gdyż zgodnie z prawem szariatu za odstąpienie od islamu muzułmaninowi grozi nawet kara śmierci ${ }^{57}$. Nie można zatem w tym przypadku przedstawić konkretnych danych liczbowych.

Trzeba stanowczo podkreślić, że wielu rdzennych Francuzów uważa, iż wyznawcy islamu mają równe prawa do kultywowania swojego wyznania, a ich żądania dotyczące powstawania meczetów są uprawnione. Rzecznik Konferencji Biskupów Katolickich Francji, Olivier Ribadeau-Dumas, stwierdził, że: Muzutmanie powinni, podobnie jak chrześcijanie i żydzi, praktykować swoją religię $e^{58}$. Należy zauważyć, że z perspektywy francuskich obywateli ważnym wyznacznikiem jest nastawienie na dialog Kościoła katolickiego z przedstawicielami wszystkich religii we Francji. Ekumenizm w tym kraju stanowi integralny element życia, nie jest zaś niezrozumiałym dodatkiem. Jak podkreśla dominikanin, ojciec Franck Lemaître ${ }^{59}$ : Francuski episkopat spotyka się regularnie dwa razy $w$ roku. Na wiosne jest to spotkanie $w$ gronie samych biskupów, natomiast jesieniq sa obecni nie tylko wspótpracownicy i specjaliści katoliccy, ale również przedstawiciele innych wyznań. Razem też poruszamy bieżące tematy spoteczne czy moralne. Oprócz tego prowadzimy intensywny dialog z żydami i muzutmanami ${ }^{60}$. Zgodnie z koncepcją Espagne'a i Wernera trzeba ustalić, czy doszło do transferu kultury, a więc do recepcji muzułmańskiego sposobu życia wynikającego bezpośrednio z wiary w Allaha we Francji.

W 2015 r. premier Francji Manuel Valls powiedział, że pomimo kilku nieporozumień dotyczących islamu w społeczeństwie francuskim, islam zostanie we Francji. [...] to druga największa grupa religijna $w$ kraju ${ }^{61}$. Wielu badaczy podkreśla, że Francja jest największym zachodnim ośrodkiem kultury muzułmańskiej, a z każdym rokiem szacunkowa liczba wyznawców tej religii w tym kraju wzrasta. Pogląd ten potwierdzają badania L'Institut Catholique de Paris i St Mary's University Twickenham w krajach europejskich i Izraelu prowadzone w latach 2014-2016 ${ }^{62}$. Podczas gdy spadek przyna-

$56 \quad$ K. Gajlewicz-Korab, Obraz muzutmanów we Francji..., s. 77.

57 H. Sherwood, P. Oltermann, European Churches Say Growing Flock of Muslim Refugees Are Converting, „The Guardian” 2016, [online] https://www.theguardian.com/world/2016/jun/05/european-churches-growing-flock-muslim-refugees-converting-christianity, 1 VIII 2018.

58 Lider muzutmanów we Francji...

59 Doktor teologii, dyrektor Wydziału ds. Jedności Chrześcijan przy episkopacie francuskim, konsultor Papieskiej Rady ds. Popierania Jedności Chrześcijan, mieszka w Paryżu.

60 Lemaitre F., Jaki jest katolicyzm we Francji?, Dominikanie.pl, 2015, [online] https://dominikanie. $\mathrm{pl} / 2015 / 02 /$ jaki-jest-katolicyzm-we-francji/, 25 XI 2017.

$61 \quad$ Lider muzutmanów we Francji...

62 S. Bullivant, Les jeunes adultes et la religion en Europe: Présentation des résultats de l'enquête sociale européenne (2014-16) en vue d'informer le Synode des évếques 2018, L'Institut Catholique de Paris, St Mary's University Twickenham, Benedict XVI Centre for Religion and Society 2018, [online] https://www.stmarys.ac.uk/research/centres/benedict-xvi/docs/2018-mar-europe-young-people-report-fra.pdf, 10 VIII 2018. 
leżności i praktyk religijnych jest szeroko rozpowszechniony, badanie wykazuje bardzo duże rozbieżności między krajami. Spośród młodych Francuzów aż 64\% deklaruje brak wyznania, $23 \%$ stanowią katolicy, a 10\% wyznawcy islamu. Ten ostatni jest najwyższym wskaźnikiem spośród wszystkich w badanych krajach Europy ${ }^{63}$.

Kolejne rządy od lat 80 . XX w. podejmowały próby stworzenia pewnej charakterystycznej dla Francji odmiany islamu, której celem byłaby integracja muzułmańskiej mniejszości w tym kraju i zwalczanie islamistycznego ekstremizmu poprzez uodpornienie wyznawców na radykalne interpretacje. Również z tego względu dziś nie mówi się już o „islamie we Francji”, ale dąży do „francuskiego islamu”. Nawołuje do niego m.in. Tareq Oubrou, lider społeczności islamskiej w Bordeaux, definiujący go jako duchowy islam wyrażajacy się w jezyku obowiazujacych republikańskich wartości ${ }^{64}$. Deklaracje Oubrou przysporzyły mu jednak przeciwników wśród niektórych grup francuskich muzułmanów, a tzw. Państwo Islamskie zaczęło nakłaniać do jego unicestwienia $^{65}$. W 2018 r. prezydent Emmanuel Macron zapowiedział w wywiadzie, że planuje ustalić zasady, w ramach których organizacje i grupy islamskie będą mogły działać i funkcjonować we Francji. Jednym z planów Macrona jest zerwanie z zagranicznymi funduszami finansującymi grupy muzułmanów we Francji. Kolejna propozycja koncentruje się na szkoleniu w kraju imamów, którzy dotąd pobierali nauki poza granicami. Poprzedni prezydent, François Hollande, podjął w tym zakresie współpracę z rządem Maroka. Zgodnie z zaleceniami Macrona, szkolenie opierałoby się na przekazywaniu wartości kulturowych, a nie religijnych, w celu wspierania pokolenia imamów "made in France" ${ }^{66}$. Nie wiadomo jednak nadal, w jaki sposób reforma ta zostanie przeprowadzona, gdyż trudność stanowić będzie sformułowanie takich zapisów, które nie będą niezgodne z ustawą o rozdziale państwa od Kościoła.

Podsumowując ten wątek, należy podkreślić, że w omawianym przypadku doszło już do transferu kultury, którego nie należy jednak utożsamiać z całkowitą islamizacją społeczeństwa, a z trwałym przeniknięciem kultury islamu i jego wpływem na sytuację gospodarczą, społeczną i kulturową Francji. Laickość obywateli ułatwiła zakorzenienie się islamu jako alternatywy dla katolicyzmu. Swój udział w tym transferze zaznaczają imigranci oraz rdzenni Francuzi czerpiący z „supermarketu kultury”. Warto jednak zwrócić uwagę na to, że nie jest on jeszcze w pełni zakończony. Nie ma bowiem - i pewnie długo nie będzie - kompromisu łączącego wartości kluczowe dla narodu francuskiego - republikańskie i laickie - z tymi wynikającymi z wiary i kultury muzułmańskiej.

63 Tamże, s. 6.

64 J. McAuley, A French Imam's Argument for Why Islam Belongs in France, „The Washington Post” 2016, [online] https://www.washingtonpost.com/world/europe/a-french-imams-argument-for-why-islam-belongs-in-france/2016/09/02/b8377348-6ead-11e6-993f-73c693a89820_story.html?utm_ term=.7cd628f4244f, 5 XI 2017.

65 Tamże.

${ }^{66}$ K. Piser, A New Plan to Create an 'Islam of France', „The Atlantic” 2018, [online] https://www. theatlantic.com/international/archive/2018/03/islam-france-macron/556604/, 10 VIII 2018. 
Niektórzy badacze jednak w inny sposób tłumaczą kryzys wiary katolickiej we Francji i wzrost liczby ateistów. Marc Fumaroli jako przyczynę osłabienia wiary wskazał umasowienie kultury i wynikające z niego potrzeby społeczeństwa konsumpcyjnego: Obserwuje się także, w tych samych przedsiębiorczych $i$ względnie dostatnich krajach, wycofanie się z wiary, a w kazdym razie z praktyk religijnych: nie kościót czy swiatynia, lecz muzeum staje się celem niedzielnych spacerów, wieczorna rodzinna modlitwę zastępuje w petni świeckie biesiadowanie przed ekranem telewizora. Nowoczesna Francja nie uniknęta ani spoteczeństwa konsumpcyjnego, ani poszukiwania kultury jako substytutu religii ${ }^{67}$.

Zygmunt Bauman nazywał konsumpcjonizm typem uktadu spotecznego, [...] atrybutem spoteczeństwa ${ }^{68}$, który napędza jego istnienie i - będąc ściśle związanym z procesami integracji i dezintegracji - odgrywa istotną rolę w kształtowaniu tożsamości społecznej. W społeczeństwie konsumpcyjnym, jak wynika z idei Mathewsa, nie myśli się o tożsamości jako o przypisanej, niezmiennej i narzuconej, ale uważa się, że buduje się ją przez całe życie. Cechuje ją płynność i niestabilność. Dlatego dla konsumenta liczy się produkt, a dla producenta sprzedaż. Również kultura została utowarowiona i sprzedawana jest w pakietach. Globalnie obserwuje się wzrost zapotrzebowania na rozrywkę, które zaspokaja wykreowana turystyka, spektakle, wszelkiego rodzaju wystawy, parki rozrywki, galerie handlowe ${ }^{69}$. Globalizacja, jak zauważa Piotr Siuda, zależy od strategii wielkich ponadnarodowych koncernów medialno-rozrywkowych, ulokowanych w krajach centrum, a wtaściwie w jednym kraju - Stanach Zjednoczonych ${ }^{70}$. Amerykanizacja kultury francuskiej jest widoczna zarówno w rozwijaniu turystyki we Francji, jak i - co znamienne - w kuchni, która od pokoleń jest symbolem narodowej tożsamości i odrębności Francuzów.

Kuchnia narodowa Francji od wieków zaliczana jest do kategorii sztuki. Opiera się na produktach spożywczych charakterystycznych dla danego regionu, a tradycyjne specjały wyróżniają poszczególne części kraju. We Francji powstała wykwintna i bogata haute cuisine (wysoka kuchnia) czy bardziej przystępna cenowo, lekka, ale równie elegancka nouvelle cuisine (kuchnia nowa). Kuchnia to nie tylko potrawy, ale przede wszystkim przepisy, specyficzny sposób przygotowania posiłku, serwowania. Kluczowe znaczenie ma także moment wspólnego biesiadowania i celebrowania efektów pracy kucharzy czy gospodyń domowych. Jedzenie jest czynnościa catkowicie kulturowa, jakkolwiek sposób przygotowania positków, sktadniki i formy ucztowania ewokuja sensy „wyszukanej naturalności ${ }^{\text {"T1}}$. Coraz częściej zwraca się jednak uwagę na powolną, ale widoczną amerykanizację tamtejszej gastronomii.

M. Fumaroli, Państwo kulturalne..., s. 141.

M. Fumaroli, Państwo kulturalne..., s. 141.

70 P. Siuda, Homogenizacja i amerykanizacja globalnej popkultury, „Kultura - Historia - Globalizacja” 2015, nr 10, s. 186.

71 A. Wieczorkiewicz, Jeść jak tubylcy, [w:] Opowiadanie w perspektywie badań porównawczych, red. Z. Mitosek, Kraków 2004, s. 272. 
Charakterystycznym zjawiskiem jest mcdonaldyzacja. Stephen Clarke w książce Merde! Rok $w$ Paryżu pisze, że w przeciwieństwie do lansowanego wizerunku Francuzi lubia fast foody. [...] większość $z$ nich w czasie lunchu albo weekendowego wypadu z rozkoszq pochtania hamburgery ${ }^{72}$, podczas gdy jeszcze kilkanaście lat wcześniej Fumaroli twierdził: Burzymy się przeciwko McDonaldom na bulwarze Saint-Michel ${ }^{73}$. Dziś młodzi Francuzi często umawiają się w „McDo”. We Francji fast food odgrywa ważną rolę w rozwoju konsumpcji poza miejscem zamieszkania. Wkrótce po wprowadzeniu na rynek amerykańskich barów szybkiej obsługi pojawiła się pierwsza europejska sieć Quick, założona w 1971 r. przez belgijskiego przedsiębiorcę barona François Vaxelaire’a. Na francuskim rynku pojawiła się dziewięć lat później. W lipcu $1980 \mathrm{r}$. dokonano otwarcia Quicka na jednej z głównych ulic Aix-en-Provence, Cours Mirabeau $^{74}$. Od tego czasu sieć szybko zaczęła się rozwijać i otwierać kolejne bary. Co ciekawe, w listopadzie 2010 r. w niektórych restauracjach tej firmy na terenie Francji wprowadzono halal menu, dostosowane do przepisów diety islamskiej, usuwając $\mathrm{z}$ niego wieprzowinę. Dla przykładu boczek w hamburgerach zamieniono na smażonego indyka ${ }^{75}$. Spotkało się to z ostrą reakcją grup katolickich, gdyż uznano, że brak alternatywnego menu jest dyskryminacją. Jest to kolejny efekt wcześniej omawianej islamizacji.

Inny przykład związany z amerykanizacją kultury kulinarnej we Francji ukazuje Michael Sadler. Wspomina, jaki czekał go zawód, gdy kiedy poszukiwał naturalnych, nieskażonych masową konsumpcją tradycyjnych francuskich produktów, chłop na farmie we wsi zaprowadził go do swego „skarbu”: Tam, niczym absurdalny ottarz pośrodku tego średniowiecznego gnojowiska, stata jego duma i radość. Dwustupięćdziesięciolitrowa, $z$ dwuletnia gwarancja, wyprodukowana w Polsce zamrażarka [...]. I co zobaczytem? Nieprzebrane stosy paczek chrupiacych wiejskich ziemniaczków McCain's, niezliczone mrożone bagietki przemystowe z hipermarketu Leclerc ${ }^{76}$. Przykład ten pokazuje, że zmiany w myśleniu o gastronomii zachodzą nie tylko w miastach, ale również na wsi.

Odnosząc się do myśli Espagne’a i Wernera, zapytać trzeba o powody tych przemian. Odpowiedzieć można myślą Mathewsa, że jest to efekt europejskiego „supermarketu kultury”. Zniesienie kontroli osób przekraczających granice między członkami układu z Schengen odniosło kulturowe skutki widoczne w upodobaniach żywnościowych. Rynek europejski, na terenie którego zapewniony jest swobodny przepływ osób, towarów, usług i kapitału, umożliwił producentom rozszerzenie zasięgu działalności. Jednolity rynek stał się także atrakcyjny dla inwestorów spoza Unii Europejskiej. Amerykanom

72 S. Clarke, Merde! Rok w Paryżu, przeł. A.B. Ciepłowska, Warszawa 2006, s. 141.

73 M. Fumaroli, Państwo kulturalne..., s. 41.

74 Notre histoire, Quick.fr, 2017, [online] https://www.quick.fr/lys-lez-lannoy/histoire, 14 XII 2017.

75 H. Samuel, French Fast Food Chain Makes Menus Halal, „The Telegraph” 2010, [online] http://www. telegraph.co.uk/news/worldnews/europe/france/7245050/French-fast-food-chain-makes-menus-halal.html, 12 XI 2017.

76 M. Sadler, Anglik w Paryżu. Edukacja kontynentalna, przeł. A.P. Zakrzewski, Bielsko-Biała 2010, s. 109-110. 
jest tatwo wejść na rynek europejski. [...] Przedsiębiorcy amerykańscy moga brać udziat w przetargach $w U E^{77}$. Konkurencja dała konsumentowi większy wybór i zmobilizowała koncerny do zwiększenia ekspansji.

Innym powodem, który wspomógł zakorzenienie w kulturze gastronomicznej Francji jedzenia typu fast food oraz półproduktów czy też przygotowanych już do podania produktów mrożonych, jest współczesny sposób życia. Życie stało się niekończącym się maratonem pomiędzy obowiązkami w pracy, w domu, w szkole. Człowiek żyje w ciągłym pośpiechu, nie mając czasu na przyrządzanie czasochłonnych posiłków, zgodnych $\mathrm{z}$ tradycją. Wtedy „z pomocą” przychodzą mu produkty gotowe. Młode pokolenia wychowywane w ciąglym biegu są przyzwyczajone do spożywania posiłków w barach szybkiej obsługi, a korzystanie z gotowych dań do podgrzania nie jest dla nich niczym nowym. $Z$ tego względu można uznać, iż doszło we Francji do transferu kultury w dziedzinie gastronomii.

Należy jednak podkreślić, że francuskie dziedzictwo kulinarne jest powodem dumy Francuzów i nadal zachowuje fundamentalne znaczenie dla ich sposobu życia. Według badania sondażowego przeprowadzonego w 2010 r. i opublikowanego w „Libération”, aż 79 proc. Francuzów lubi gotować, a dla 93 proc. spędzanie czasu przy rodzinnym stole pozostaje instytucją ${ }^{78}$. Są to rekordowe liczby w czasach ponowoczesnych. Obywatele kultywują tradycje kulinarne w trakcie uroczystości rodzinnych czy świąt, podtrzymując i zachowując kulturową odrębność. Słynny przewodnik Gault et Millau, który powstał z inicjatywy dwóch francuskich dziennikarzy i krytyków kulinarnych - Henriego Gault i Christiana Millau, propagatorów nouvelle cuisine, ukazuje się każdego roku w edycjach narodowych. Jak podkreśla dyrektor generalny Gault et Millau, Côme de Chérisey, smak jest silnie związany z miejscem, geografią, a także kulturą, choć powoli się globalizuje ${ }^{79}$. Celem podtrzymywania kulinarnej odrębności i konsekwencją starań czynionych na rzecz uznania wspólnoty stołu jako nośnika tradycji i kultury było także wpisanie - w 2010 r. - francuskiej tradycji biesiadnej na listę światowego niematerialnego dziedzictwa UNESCO ${ }^{80}$. Wszystkie te przykłady wskazują, że transfer amerykańskiej kultury kulinarnej nie zaburzył jak dotąd roli kuchni francuskiej i wspólnego zasiadania do stołu we Francji.

T. Pisula, Polski rynek jest atrakcyjny dla amerykańskich inwestorów. Nasze relacje biznesowe są bardzo dobre, wPolityce.pl, 2017, [online] https://wpolityce.pl/polityka/346996-tomasz-pisula-polski-rynek-jest-atrakcyjny-dla-amerykanskich-inwestorow-nasze-relacje-biznesowe-sa-bardzo-dobre?strona $=2,15$ XII 2017.

78 Francuska gastronomia dziedzictwem UNESCO, Wprost.pl, 2010, [online] https://www.wprost. $\mathrm{pl} / 218068,19$ XII 2017.

79 Ł. Modelski, Piąty smak. Rozmowy przy jedzeniu, Kraków 2014, s. 274.

80 N. Moreno-Kamińska, Francuskie święta i festiwale kulinarne - perspektywa kulturoznawcza, „Zabawy i Zabawki. Studia Antropologiczne” 2017, nr 15, s. 165-166. 


\section{PODSUMOWANIE}

Laickość Francji i jej obywateli, kształtująca się przez dekady, ułatwiła zakorzenienie się islamu jako alternatywy dla katolicyzmu. W artykule przedstawiony został wpływ współczesnej migracji ludności oraz globalizacji na kulturę francuską. Zjawiska te, jak pokazały wybrane przykłady, prowadzą do nieustannych przemian społecznych, przenikania się francuskiej i muzułmańskiej wspólnoty oraz przemieszania grup etnicznych w różnych regionach Francji. W konsekwencji prowadzą one do powolnego zacierania się granic kulturowych w czasach ponowoczesnych.

Należy stwierdzić, że Francuzi podtrzymują tożsamość narodową w kontekście transferu kultury, mimo że nie został on w pełni ukształtowany, a sytuacja mniejszości islamskiej jest dynamiczna. $\mathrm{Z}$ pewnością francuski naród zabiega w wielu obszarach o podtrzymywanie swoich wartości, odrębności i tradycji. Widać to choćby w działaniach podejmowanych na szczeblach władzy, m.in. w wypowiedziach przedstawicieli rządu czy prezydenta Emmanuela Macrona z marca 2018 r. Świadczą o tym także protesty niektórych grup narodowych przeciwko budowaniu kolejnych meczetów czy dostosowywaniu menu sieci Quick do ścisłych wymogów islamu. Nie oznacza to jednak, że Francuzi jako naród są przeciwni kulturze i religii muzułmańskiej. Społeczeństwo francuskie nadal jest podzielone. Jedni podkreślają, że dla podtrzymania francuskiej tożsamości ważne jest wzajemne poszanowanie, zachowanie równowagi i dialog obywatelski, łączący wszystkich, niezależnie od tego, jaką wiarę wyznają. Oddzielenie kwestii wiary od państwa jest bowiem we Francji wartością samą w sobie i pozostałością po wielkiej rewolucji, która do dziś jest chlubą tamtejszego społeczeństwa. Świadczą o tym wielkie uroczystości odbywające się rokrocznie 14 lipca w całym kraju z okazji Święta Narodowego Francji (fr. Fête Nationale Française), upamiętniającego zburzenie Bastylii. Wielu Francuzów zmienia wiarę, przechodząc na islam czy mniej skrajny tzw. islam francuski. Inni są przeciwni temu wyznaniu i związanej z nim kulturze, m.in. bojąc się jego radykalizacji i ekstremistycznych dążeń niektórych grup. Znaczącą rolę bowiem w szerzeniu się niepokoju społecznego odegrały zamachy terrorystyczne zorganizowane przez wyznawców doktryny muzułmańskiej.

Należy jednocześnie podkreślić, że część muzułmanów, m.in. z wdzięczności dla grup chrześcijańskich oferujących wsparcie czy też w oczekiwaniu, że konwersja może wspomóc ubieganie się o azyl, zmienia wyznanie na katolickie ${ }^{81}$. Trudno zatem jednoznacznie stwierdzić, iż we Francji przewagę posiadają konwersje na islam. Wypowiedzi przywódców religijnych nie pozwalają także na sformułowanie w pełni klarownych wniosków.

Procesy migracji i islamizacji kultury francuskiej nie są zakończone, Francja będzie mierzyć się z nimi przez kolejne dekady. Ukazana problematyka pokazała dwie strony tych wpływów.

Podobnie jest w kwestii fast foodu, który towarzyszy społeczeństwu francuskiemu w codziennym życiu. Trzeba podkreślić, że ten typ gastronomii nie stanowi jednak

81 H. Sherwood, P. Oltermann, European Churches... 
alternatywy dla menu charakterystycznego dla wspólnych biesiad w gronie rodziny czy znajomych, z zachowaniem kolejności serwowania dań, podaniem tradycyjnego talerza serów czy doborem odpowiedniego wina we właściwym kieliszku do każdej potrawy.

Wpisanie „francuskiej tradycji biesiadnej” na listę światowego niematerialnego dziedzictwa UNESCO stanowi przykład sposobu, w jaki Francuzi zabiegają o podtrzymywanie odrębności i tożsamości kulturowej. W trakcie posiłków organizowanych w ramach specjalnych okazji, takich jak urodziny czy święta, jeszcze mocniej uwyraźnia się dbałość o zachowanie tradycyjnych obrzędów. Dla narodu francuskiego kuchnia jest powodem do dumy, dlatego tradycja biesiadna łączy się z koniecznością odbycia ceremoniału, którego uczone są kolejne pokolenia.

Dla żyjącego na co dzień w pośpiechu Francuza łatwiejszą i szybszą opcją od wyszukanych i często czasochłonnych potraw stało się pożywienie typu fast food. Nie oznacza to odrzucenia wartości ugruntowanych w kulturze francuskiej.

Gordon Mathews pisze o kulturze, że: termin ten nadal zachowuje znaczenie, jeżeli tylko potrafimy potaczyć tradycyjna idee kultury jako sposobu życia pewnego ludu z bardziej wspótczesna koncepcja kultury jako informacji i tożsamości dostępnych w globalnym supermarkecie kultury ${ }^{82}$. Ta perspektywa jest niezwykle trafna w kontekście podsumowania zmian zachodzących w kulturze francuskiej. Jak pisali Espagne i Werner, w kulturze przyjmującej zakorzenią się elementy z jej perspektywy deficytowe. Można przyjąć, że te zmiany wpisują się w ideę rewolucji: „Wolność, Równość, Braterstwo”. Kluczem do zachowania tożsamości narodowej, a jednocześnie korzystania z odmienności innych kultur są równowaga, umiarkowanie, dialog. Stanowią one wyzwanie dla Francji, ale także drogowskaz dla innych państw, co widać w prawodawstwie Unii Europejskiej. Inspirująco napisał Fumaroli: naturalnym elementem tradycji francuskiej jest jej zdolność do duchowej odpowiedzi na wyzwanie kolejnych odmian nowoczesności. Tej wtaśnie zdolności świat szuka i pragnie znajdować we Francji, potrzebując jej bardziej aniżeli oficjalnych sloganów i cyfr „Kultury ${ }^{\text {»3 }}$.

\section{BIBLIOGRAFIA}

Ardagh J., Jones C., Wielkie kultury świata. Francja, przeł. J. Pierzchała, M. Dziekan, Warszawa 1998.

Bainville J., Dzieje Francji, przet. T. Stryjeński, Komorów 2010.

Baszkiewicz J., Francja nowożytna. Szkice z historii wieków XVII-XX, Poznań 2002.

Baszkiewicz J., Francja w Europie, Wrocław 2006.

Bauman Z., Konsumowanie żcia, przeł. M. Wyrwas-Wiśniewska, Kraków 2009.

Brandon S., Podróżuj, gotuj, bądźz zdrowa, przel. B. Wrońska, Warszawa 2014.

Brillat-Savarin A., Fizjologia smaku albo Medytacje o gastronomii doskonatej, przeł. J. Guze, Warszawa 2015.

82 G. Mathews, Supermarket kultury..., s. 13.

83 M. Fumaroli, Państwo kulturalne..., s. 290. 
Bullivant S., Les jeunes adultes et la religion en Europe: Présentation des résultats de l'enquête sociale européenne (2014-16) en vue d'informer le Synode des évêques 2018, L'Institut Catholique de Paris, St Mary's University Twickenham, Benedict XVI Centre for Religion and Society 2018, [online] https://www.stmarys.ac.uk/research/centres/benedict-xvi/docs/2018-mar-europe-young-people-report-fra.pdf, 10 VIII 2018.

Clarke S., Merde! Rok w Paryżu, przeł. A.B. Ciepłowska, Warszawa 2006.

Cobban A., A History of Modern France, Vol. 1, Harmondsworth 1965.

Dramatyczna skala przemian kulturowych we Francji. W ćwierć wieku liczba chrztów zmniejszyta się o ponad potowę!, Wolność24.pl, 2017, [online] http://wolnosc24.pl/2017/05/08/ dramatyczna-skala-przemian-kulturowych-we-francji-w-cwierc-wieku-liczba-chrztow-zmniejszyla-sie-o-ponad-polowe/, 19 XII 2017.

Francja. Przewodnik ilustrowany, red. F. Duncan, przeł. A. Kaczmarczyk, E. Czarnowska-Fenrych, Warszawa 2014.

Francuska gastronomia dziedzictwem UNESCO, Wprost.pl, 2010, [online] https://www.wprost. $\mathrm{pl} / 218068,19$ XII 2017.

Freise M., Próba typologii podstawowych zagadnień komparatystycznych, „Litteraria Copernicana" 2015, nr 2.

Fumaroli M., Państwo kulturalne. Religia nowoczesności, przeł. H. Abramowicz. J.M. Kłoczowski, Kraków 2008.

Gajlewicz-Korab K., Obraz muzutmanów we Francji w tamtejszych tygodnikach opinii, Warszawa 2011.

Gaudeul J.-M., Changements d'affiliation entre christianisme et islam, „Études” 2004, vol. 11.

Il n'y a pas assez de mosquées en France, „Le Figaro” 2015, [online] http://www.lefigaro.fr/flash-actu/2015/04/07/97001-20150407FILWWW00063-il-n-y-a-pas-assez-de-mosquees-en-france.php, 10 VIII 2018.

Islam: The World's Fastest Growing Religion, BBC News, 2017, [online] https://www.bbc.com/ news/av/world-39279631/islam-the-world-s-fastest-growing-religion, 1 VIII 2018.

Kielan-Glińska I., Muzutmanie w laickiej Francji (1974-2004). W kierunku integracji czy separatyzmu?, Kraków 2009.

Kowalski J., Loba A. i M., Prokop J., Dzieje kultury francuskiej, Warszawa 2005.

Lemaitre F., Jaki jest katolicyzm we Francji?, Dominikanie.pl, 2015, [online] https://dominikanie.pl/2015/02/jaki-jest-katolicyzm-we-francji/, 25 XI 2017.

Lider muzutmanów we Francji: zamieńmy puste kościoty na meczety, TVN24.pl, 2015, [online] https://www.tvn24.pl/wiadomosci-ze-swiata,2/lider-muzulmanow-we-francji-zamienmy-puste-koscioly-na-meczety,551981.html, 25 XI 2017.

Magnone L., Emisariusze Freuda. Transfer kulturowy psychoanalizy do polskich sfer inteligenckich przed drugq wojna światowa, t. 1, Kraków 2016.

Mathews G., Supermarket kultury. Kultura globalna a tożsamośćjednostki, przeł. E. Klekot, Warszawa 2005.

McAuley J., A French Imam's Argument for Why Islam Belongs in France, „The Washington Post" 2016, [online] https://www.washingtonpost.com/world/europe/a-french-imams-argument-for-why-islam-belongs-in-france/2016/09/02/b8377348-6ead-11 e6-993f-73c693a89820_story.html?utm_term=.7cd628f4244f, 5 XI 2017. 
Michalak M., Muzutmanie to wielki problem Francji, Interia.pl, 2017, [online] http://fakty.interia.pl/raporty/raport-wybory-prezydenckie-francja-2017/korespondencje/news-muzulmanie-to-wielki-problem-francji,nId,2389361, 13 XI 2017.

Mtodzi Francuzi przechodza na islam, Pch24.pl, 2012, [online] http://www.pch24.pl/mlodzi-francuzi-przechodza-na-islam,10282,i.html, 10 XII 2017.

Modelski Ł., Piaty smak. Rozmowy przy jedzeniu, Kraków 2014.

Moreno-Kamińska N., Francuskie święta i festiwale kulinarne - perspektywa kulturoznawcza, „Zabawy i Zabawki. Studia Antropologiczne” 2017, nr 15.

Moreno-Kamińska N., Problematyka tożsamości kulturowej spoteczeństw ponowoczesnych $w$ naukach humanistycznych - aspekty kulturoznawcze, [w:] Nauki spoteczne i humanistyczne wobec wyzwań XXI wieku, red. K. Pujer, Wrocław 2017.

Nadal trwaja zamieszki we Francji, PAP, 2005, [online] http://www.money.pl/archiwum/wiadomosci/artykul/nadal;trwaja;zamieszki;we;francji,210,0,130002.html, 26 XI 2017.

Notre histoire, Quick.fr, 2017, [online] https://www.quick.fr/lys-lez-lannoy/histoire, 14 XII 2017.

Pachocka M., Polityka imigracyjna i integracyjna Francji w okresie prezydentury Nicolasa Sarkozy'ego - zarys problemu, [w:] Wokót problematyki migracyjnej. Kultura przyjęcia, red. J. Balicki, M. Chamarczuk, Warszawa 2013.

Piser K., A New Plan to Create an 'Islam of France', „The Atlantic” 2018, [online] https://www. theatlantic.com/international/archive/2018/03/islam-france-macron/556604/, 10 VIII 2018.

Pisula T., Polski rynek jest atrakcyjny dla amerykańskich inwestorów. Nasze relacje biznesowe sq bardzo dobre, wPolityce.pl, 2017, [online] https://wpolityce.pl/polityka/346996-tomasz-pisula-polski-rynek-jest-atrakcyjny-dla-amerykanskich-inwestorow-nasze-relacje-biznesowe-sa-bardzo-dobre?strona=2, 15 XII 2017.

Poirriera Ph., Société et Culture en France depuis 1945, Paris 1998.

Potel J.-Y., Rapacki M., Frybes M., Francja ta sama czy inna?, Warszawa 2009.

Prykowska-Michalak K., Kurtyna w górę! Relacje między teatrem polskim a teatrem niemieckim po 1990 roku, Łódź 2012.

Przedpełski B., Kontrowersje wokót jansenizmu, „Rocznik Teologiczny” 2010, t. 52, z. 1-2.

Sadler M., Anglik w Paryżu. Edukacja kontynentalna, przeł. A.P. Zakrzewski, Bielsko-Biała 2010. Samuel H., French Fast Food Chain Makes Menus Halal, „The Telegraph” 2010, [online] http:// www.telegraph.co.uk/news/worldnews/europe/france/7245050/French-fast-food-chain-makes-menus-halal.html, 12 XI 2017.

Sherwood H., Oltermann P., European Churches Say Growing Flock of Muslim Refugees Are Converting, „The Guardian” 2016, [online] https://www.theguardian.com/world/2016/ jun/05/european-churches-growing-flock-muslim-refugees-converting-christianity, 1 VIII 2018.

Siuda P., Homogenizacja i amerykanizacja globalnej popkultury, „Kultura - Historia - Globalizacja” 2015, nr 10.

Straszewicz L., Francja, Warszawa 1972.

Szostkiewicz A., Demografia: tajna broń muzutmanów? Niedtugo będzie ich więcej niż chrześcijan, Polityka.pl, 2017, [online] https://www.polityka.pl/tygodnikpolityka/swiat/ 
1698276,1,demografia-tajna-bron-muzulmanow-niedlugo-bedzie-ich-wiecej-niz-chrzescijan.read, 1 VIII 2018.

Toussaint-Samat M., Historia naturalna i moralna jedzenia, przeł. A.B. Matusiak, M. Ochab, Warszawa 2015.

Wieczorkiewicz A., Jeść jak tubylcy, [w:] Opowiadanie w perspektywie badań porównawczych, red. Z. Mitosek, Kraków 2004.

Natalie MORENO-KAMIŃSKA - doktorantka Wydziału Filologicznego Uniwersytetu Łódzkiego w Instytucie Kultury Współczesnej, absolwentka dziennikarstwa i komunikacji społecznej w specjalności public relations i branding oraz kulturoznawstwa w specjalności promocja sztuki UŁ. Interesują ją zagadnienia z zakresu dziedzictwa kulturowego, turystyki kulturowej, sztuki oraz public relations. Ze względu na polsko-francuskie pochodzenie pasjonuje ją dziedzictwo kultury francuskiej. 